International Journal of Social Science And Human Research

ISSN(print): 2644-0679, ISSN(online): 2644-0695

Volume 04 Issue 10 October 2021

DOI: 10.47191/ijsshr/v4-i10-44, Impact factor-5.586

Page No: 2985-2987

\title{
Cognitive Principles of Information Coverage in Literary Texts in English and Uzbek
}

\section{Feruza Fayzullaevna Tairova}

Senior Lecturer, National Institute of Art and Design named after Kamoliddin Behzod of the Academy of Arts of Uzbekistan

\begin{abstract}
This article discusses the cognitive principles of information coverage in literary texts in English and Uzbek. A literary text, resulting from a combination of such texts and artistic activities that form an artistic discourse can be fully described in the form of a certain structured space of a number of artistic images. These images are formed in the consciousness of the author and the reader, as participants in artistic communication, peculiar linguistic forms of existence of aesthetic-artistic concepts, they can be characterized as a unit used to teach linguo-cognitive analysis of the proposed artistic discourse. Within the framework of psycholinguistics, the mechanisms of perception and generation of speech were investigated, as well as the mechanisms of studying language as a system of signs that is preserved in human consciousness.
\end{abstract}

KEYWORDS: cognitive principles, English language, Uzbek language, literary text, combination, artistic activities, artistic discourse, artistic images, consciousness, author, reader, participants, artistic communication, peculiar linguistic, aesthetic-artistic concepts, linguo-cognitive analysis, perception, generation, psycholinguistics.

\section{INTRODUCTION}

Cognitive linguistics has taken a special place in the paradigm of the concepts of modern linguistics. Cognitive science is one of the new stages in the study of the connection between thinking and language, the role of language for a person and a person in language. The results of studies of neurophysiology and neurolinguistics helped to come to the conclusion that not only language activity occurs in the brain, but also that different parts of the brain are responsible for different types of language activity. The next stage in the study of the problem of the relationship between thinking and language is psycholinguistics. Within the framework of psycholinguistics, the mechanisms of perception and generation of speech were investigated, as well as the mechanisms of studying language as a system of signs that is preserved in human consciousness.

\section{THE MAIN FINDINGS AND RESULTS}

Cognitive linguistics as a direction of linguistic research developed in the second half of the 70s of the XX century and had a significant number of followers in the course of development. Linguistic historiography dates the emergence of cognitive linguistics to the late 1980s and early 1990s. This time stage corresponds to when the emergence of the association of cognitive linguistics was announced at a scientific conference in Duisburg and cognitive linguistics as a linguistic direction became independent.

The cognitive approach to a literary text relies on the use of important cognitive units - concepts, since without mastering the components in the cognitive base, capable of storing and transmitting cultural information, it is very difficult to carry out an adequate and equivalent version of the translation of the text. This statement is based on the fact that a high-quality literary translation of a text presupposes the presence of previously formed knowledge about the traditions, customs, literature, culture, stereotypes and history of the country of the original language.

A literary text, resulting from a combination of such texts and artistic activities that form an artistic discourse can be fully described in the form of a certain structured space of a number of artistic images. These images are formed in the consciousness of the author and the reader, as participants in artistic communication, peculiar linguistic forms of existence of aesthetic-artistic concepts, they can be characterized as a unit used to teach linguo-cognitive analysis of the proposed artistic discourse.

It should be noted that the aforementioned interpretation and perception of the artistic information contained in the text when teaching English language is also assessed as an important cognitive activity. Mediated communication between the author and the reader of the work with the described characters is carried out using artistic concepts. Consistent work with artistic images contained in artistic concepts forms skills that allow for a more adequate and equivalent translation artwork.

Beginning in the 1990s, Uzbek scholars began to study the theoretical problems of textual linguistics. In this regard, the textbook "Linguistic analysis of literary texts" by B. Urinbaev, R. Kungurov, J. Lapasov is of special importance. The 


\section{Cognitive Principles of Information Coverage in Literary Texts in English and Uzbek}

introductory part of this work is called Text - the object of linguistic analysis. Current issues such as text types, their general and specific features, methodological principles of linguistic analysis of the text, the problems of text creation, the choice of means of expression and their role in the structure of the text are illustrated by the facts of the Uzbek language. Professor E. Kilichev's textbook "Linguistic analysis of the text" (2000) provides examples of the text and its linguistic analysis. Most importantly, the work provides examples of exercises for reading and analyzing poetic and prose texts, studying the text "under a linguistic microscope".

However, along with the presence of general categories in grammatical the structure of the languages under consideration, there are many differences and features of the expression of the category of personality in these languages, due, as mentioned earlier, to the fact that the structure of the language reflects the structure of the consciousness of a particular people. So, in contrast to the Russian language, in English for expressing the text category of personality, modal verbs play an important role, which have a wide range of meanings, participate in the coordination of tenses and in the construction of forms of the subjunctive mood. In English, the presence of a subject expressed by a pronoun is mandatory in impersonal sentences, while in Russian there is no such need. At the same time, the use of "you" as a subject personal pronoun creates a shade of personal appeal even when the sentence is impersonal in meaning and has a generalizing character. Wed: " $<\ldots$... and you felt that his affability was a duty $<\ldots$..>' (IV.S. Maugham. "Rain"). "And it was felt that his courtesy was only a manifestation of a sense of duty" (translated by J.C).

An analysis of the means of expressing the text-forming category of personality showed that it is necessary to take into account the pragmatic aspect of a literary text, which focuses not only on a specific verbally expressed text, but primarily on background information about the subject, his intentions, conditions and purposes of communication. When considering the textual category of personality in the pragmatic aspect, not only the text is taken into account as a result of the speaker's speech activity, but also the whole sum of "the speaker plus his statement" is taken into account. The means of expression of the category of personality have significant pragmatic potential in both Uzbek and English. At the same time, as the study of text fragments has shown, the essential characteristics of these tools are their evaluativeness, imagery and information content.

It is possible that, by analogy with the category of personalities at the sentence level, the textual category of personalities also has a field structure. We have given a tentative description of the functional-semantic field of the text category of personality, since it is necessary to analyze a larger volume of texts of a larger time slice in order to trace the dynamics of the means of expression of this category. By subject-centrism, we mean the fact that the subject of artistic narration makes absolute his own spiritual, mental position. Subject-centrism is one of the most important conditions for the personal understanding of a literary text. It organizes the entire figurative system of the text and also embodies the general artistic value of the work, determines the author's tactics used in it. Thus, subject-centrism is the defining aspect of the literary text and acts as a speech condition for the representation of the category of personality in the text. In whatever form the author's position is expressed in an artistic text, the author behind the text is "all-knowing" about the artistic world he has created and has the gift of indirect speaking.

The choice of linguistic means by the writer, as is commonly believed, is determined by his speech and artistic conception, theme, ideal, plot of the work. But, as the analysis shows, this choice is determined by another circumstance, the personality of the pseudo-author (or, according to another terminology, not the author's own), his age, social belonging, the level of his education, his/her character.

\section{CONCLUSION}

In conclusion, cognitive units and cognitive structures in the process of understanding a literary text analyzes in Uzbek and English language, the existing theoretical approaches to the problem of identifying a mental cognitive unit and develops the concept of such functional cognitive units and cognitive structures that the recipient operates in the process of understanding and interpreting a literary text. Reading is one of the ways to learn English. Regular reading in English not only allows you to replenish your vocabulary in the most natural, enjoyable and accessible way, but also to observe the practical application of grammatical structures in ready-made texts.

\section{REFERENCES}

1) Shodikulova, A. Z. (2021). COGNITIVE INTERPRETATION OF THE PHENOMENON OF METONYMY. Scientific reports of Bukhara State University, 5(1), 136-146.

2) Brown, K. (2005). Encyclopedia of language and linguistics (Vol. 1). Elsevier.

3) Alimov, B. (2020). MEDIA IMAGE AS AN IMPORTANT MEANING OF UZBEKISTAN'S IMAGE FORMATION: THEORETICAL AND COGNITIVE ASPECTS. Philology Matters, 2020(3), 205-233.

4) Ashurova, D. U., \& Galiyeva, M. R. (2012). Text linguistics. Tashkent: Tafakkur Qanoti, 316.

5) Vladimirovna, S. V. COGNITIVE ANALYSIS OF VERBS IN ENGLISH AND RUSSIAN LANGUAGES IN THE CONTEXT OF IDIOMS AND POLYSEMANTIC VERBS. 


\section{Cognitive Principles of Information Coverage in Literary Texts in English and Uzbek}

6) AHMEDOV, O. STYLISTIC COLOUR AS AN OBSTACLE IN TRANSLATION OF TAXATION AND CUSTOMS TERMS (ON ENGLISH AND UZBEK MATERIALS).

7) Yulduz, S., Sardor, S., \& Maftuna, A. (2021). The Psychological and Cognitive Benefits of Multilingualism. Annals of the Romanian Society for Cell Biology, 591-596.

8) Shirinova, R., Kuldashova, M., Rakhimova, G., Shamuratova, G., \& Eshmamatov, I. (2020). Representation of the national picture of the world in literary translation. International Journal of Advanced Science and Technology, 29(5), 1446.

9) KHUSENALIYEVNA, K. D., CHORIYEVNA, A. Z., \& ORAKBAYEVNA, K. D. (2021). Lexico-semantic features of technical teams of English and Uzbek languages. Journal of Contemporary Issues in Business and Government, 27(2), 4083-4088.

10) Abadzi, H. (2003). Improving adult literacy outcomes: Lessons from cognitive research for developing countries. World Bank Publications.

11) Bekchanovna, T. S. (2019). Constitutional and legal regulation of mass media and study of public opinion. Вопросы науки и образования, (23 (71)).

12) Zakirova, S. A. (2020). Computer graphics as a tool for the development of students' creative and intellectual abilities in classes on the basics of information technology. ACADEMICIA: An International Multidisciplinary Research Journal, 10(6), 1419-1423.

13) Рашидов Жамшид Хусан Угли (2020). СОВРЕМЕННЫЕ ПРОБЛЕМЫ И ТЕНДЕНЦИИ РАЗВИТИЯ КНИЖНОГО ДИЗАЙНА. Вестник науки и образования, (24-1 (102)), 106-109. 